\title{
Age discrimination: the new Regulations
}

by John Sprack

A summary of the principal changes introduced by the Employment Equality (Age) Regulations 2006, which recently came into effect.

\section{INTRODUCTION}

$\mathrm{T}$ he Employment Equality (Age) Regulations 2006 came into force on October 1, and like the Sexual Orientation Regulations and the Religion or Belief Regulations, they purport to implement the EC's Council Directive 2000/78 ("the Directive"). The main features of the Age Regulations can be summarised as prohibiting:

(a) direct discrimination

(b) indirect discrimination

(c) victimisation

(d) harassment; and

(e) instructions to discriminate

The definitions of the various categories of unlawful activity generally follow those which are familiar from other strands of discrimination law, although there are some distinctive points which are worth noting. Direct discrimination is defined as less favourable treatment by A of B "on grounds of B's age". This is defined to include "B's apparent age."

Indirect discrimination is the application of a provision, criterion or practice "which puts or would put persons of the same age group as B at a particular disadvantage when compared with other persons". "Age group" means "a group of persons defined by reference to age, whether by reference to a particular age or a range of ages".

A major difference is that direct discrimination on grounds of age is capable of being justified. The Directive (Art 6) allows Member States to permit justification of differences of treatment on grounds of age, without distinction between direct and indirect discrimination, if:

"they are objectively and reasonably justified by a legitimate aim, including legitimate employment policy, labour market and vocational training objectives, and if the means of achieving that aim are appropriate and necessary."

The Age Regulations do not use the term "justification". Instead they refer to "a proportionate means of achieving a legitimate aim”. Regulation 5 prohibits less favourable treatment on the grounds that an employee has not carried out instructions to commit an act which is unlawful by virtue of the Regulations, or has complained about such instructions.

\section{COVERAGE}

The Regulations do not cover goods and services. Their core is confined to employment (broadly defined, see below) and vocational training. They do, however, cover institutions of further and higher education (not only where the courses concerned are vocational - see reg 23). The following groups are given protection by the Regulations (individual regulations may only operate in respect of some of the groups in question):

(a) employees, who are defined (reg 2) to include:

(i) those under a contract of service;

(ii) apprentices;

(iii) those under a contract personally to do any work;

(b) office-holders;

(c) contract workers

(d) police officers including staff of the Serious Organised Crime Agency;

(e) barristers;

(f) Scottish advocates;

(g) partners;

(h) members of limited liability partnerships;

(i) persons in Crown employment;

(j) members of staff of both Houses of Parliament

There are general exceptions to the operation of the Regulations in respect of:

- $\quad$ statutory authority (reg 27);

- national security (reg 28);

- $\quad$ positive action (reg 29); 
- genuine occupational requirements (paragraphs of particular regs).

\section{PROHIBITED AREAS OF DISCRIMINATION}

The prohibited areas of discrimination for applicants and employees are set out in regulation 7 (reproduced below). It makes unlawful any discrimination in relation to the process of recruitment for the categories of person set out above. But there is an exception to the prohibition on discrimination in the recruitment process set out in regulation 7(4). This lays down that it is not unlawful to discriminate in the recruitment process against those who are:

(a) over 65 if the employer does not have a normal retirement age (NRA);

(b) over the employer's NRA if that is 65 or over;

(c) within six months of the NRA or (if there is none) the age of 65 on the date of the application for employment.

Discrimination is prohibited in relation to terms of employment, opportunities for promotion, transfer, training and other benefits. However, there is an exception in relation to benefits based on length of service, which is set out in reg 32 (reproduced below). In summary, this states:

(a) discrimination on the basis of length of service is permitted; but

(b) if the person alleging discrimination has 5 years service or more, it must "reasonably appear" to the employer that his use of the criterion of length of service "fulfils a business need of his undertaking" (eg by encouraging loyalty or motivation or rewarding experience).

The exception contained in reg 32 applies to those in categories (a) (b) (d) (g) (h) (i) and (j) in the list under the heading of "Coverage" above. There are also exceptions to the prohibition on discrimination in relation to benefits for:

(a) the national minimum wage - employers can pay workers aged 16/17 less than those aged 18/21 and both age bands less than those aged 22 and over;

(b) enhanced redundancy pay - this can be based upon the present (prima facie discriminatory) formula for statutory redundancy pay; and

(c) life assurance cover for workers who have retired early on grounds of ill health.

The default retirement age of 65 is set out in regulation 30. This states that it is not unlawful to dismiss someone who is over the age of 65 where the reason for the dismissal is retirement. The impact is that any such dismissal is excluded from the ambit of the prohibition against age discrimination. It may, however, constitute unfair dismissal, as the age limit for unfair dismissal claims has now been removed (sched 8, para 25).

Regulation 30 (the default retirement age) applies only to employees within the meaning of section 230(1) of the Employment Rights Act ("ERA") 1996 (those under a contract of employment but including Crown employees and members of Parliamentary staff). Its ambit is much narrower than that of the Regulations generally. With regard to office holders, for example, any retirement age would have to be justified (legitimate aim achieved by proportionate means).

\section{CHANGES TO UNFAIR DISMISSAL LAW}

The Regulations bring about major changes in the law of unfair dismissal. At the considerable risk of oversimplification:

- "Retirement of the employee" becomes a fair reason for dismissal.

- There is a duty placed upon the employer to consider whether the employee should continue after the retirement date.

- A procedure is laid down for such consideration which replaces the statutory DDP in respect of retirement dismissals.

- There are various presumptions as to whether retirement has been established as the reason for the dismissal.

- There is a special test for fairness in respect of retirement dismissals.

Under the duty to consider procedure:

- The employer who intends to retire an employee must notify the employee of the date upon which he intends him to retire, and of his right to make a request to continue working after that date.

- The notification must be given between six months and one year before the intended date of retirement (sched 6 , para 2). Failure to notify within these limits constitutes a separate right of action for which a tribunal shall award compensation up to eight weeks' pay

- Thereafter, the employer remains under a continuing duty to notify, until the fourteenth day before the intended date of retirement (sched 6, para 4)

- The employee may make a request to the employee not to retire on the intended date.

- The employer has a duty to consider the request.

- The employer must hold a meeting to consider the request within a reasonable period after receiving it. 
- If the request is refused, the employee must be told of his right to appeal. No reasons for the refusal need be given.

- Notice of appeal must be given as soon as is reasonably practicable after notice of the refusal, setting out grounds of appeal.

- The employee is entitled to be accompanied by a worker employed by the same employer at both the initial and the appeal meeting.

- There are transitional provisions which apply to those who are to be retired before April 1, 2007.

Schedule 8, paragraph 22 inserts a new potentially fair reason in section 98(2) of the ERA 1996: “(ba)... retirement of the employee". The employer must show that the reason is retirement, but certain presumptions are set out in sections 98ZA to $98 \mathrm{ZH}$, which are inserted in the ERA 1996 by schedule 8, paragraph 23.

\section{When retirement is the only reason for dismissal}

In summary, retirement is deemed to be the only reason for dismissal where:

(a) the employee has no normal retirement age (NRA), the employer gives the required notice (ie in accordance with para 2 of sched 6) and the dismissal takes effect on or after the employee's 65th birthday and on the intended date of retirement (s 98ZB(2));

(b) the employee has an NRA which is over 65, the employer gives the required notice and the dismissal takes effect on or after the employee has reached the NRA and on the intended date of retirement (s 98ZD(2));

(c) the employee has an NRA which is below 65 but does not amount to unlawful age discrimination, the employer has given the required notice and the dismissal takes effect on or after the employee has reached the NRA and on the intended date of retirement (s 98ZE(4)).

\section{When retirement is not the reason for dismissal}

There are a number of circumstances where retirement is deemed not to be the reason for dismissal:

(a) where the employee has no normal retirement age, but the dismissal takes effect before the employee reaches the age of 65 ;

(b) where the employee has no normal retirement age, the employer gives notice in accordance with paragraph 2 of schedule 6 , but the dismissal takes effect before the intended date of retirement notified to the employee;

(c) where the employee has a normal retirement age (whether above or below 65), but the dismissal takes effect before the employee reaches that age; (d) where the employee has a normal retirement age over the age of 65 , the employer gives notice in accordance with paragraph 2 of schedule 6 , but the dismissal takes effect before the intended date of retirement date so notified;

(e) where the employer does not notify the employee in accordance with paragraph 2 of schedule 6 , but he does notify the employee of an intended date of retirement, but the dismissal takes effect before that intended date of retirement;

(f) where the employer has a normal retirement age which is below the age of 65 , the dismissal takes effect after that age, but it is unlawful age discrimination for the employee to have that retirement age (i.e. the retirement age is not objectively justified);

(g) where the employer has a normal retirement age which is below the age of 65 , that retirement age is objectively justified, the employer has notified the employee in accordance with paragraph 2 of schedule 6 , but the dismissal takes effect before the intended retirement date.

\section{When the tribunal decides whether retirement is the reason for dismissal}

There are a few cases where it is left to the tribunal to decide whether retirement is the reason for dismissal:

(a) where the employer has not notified the employee in accordance with paragraph 2 of schedule 6 - perhaps he notified late or not at all (whether or not the employee has a normal retirement age); or

(b) where the employer notified the employee in accordance with paragraph 2 of schedule 6 , but the dismissal takes effect after the intended date of retirement.

Where the tribunal concludes that retirement is the reason for dismissal, whether or not the dismissal is fair is assessed in accordance with the new section 98ZG of the ERA 1996. This test, rather than that contained in section 98(4) is to be applied once it is established that it is a retirement dismissal.

The test amounts to a procedural fairness test. Has the employer complied with the following duties under the duty to consider procedure?

- service of notice of date of intended retirement etc.(must be by the fourteenth day before the date)

- consideration of any request to continue in employment

- holding a meeting to consider the request

- holding any appeal if notice of appeal served 
If there has been a failure on the part of the employer to comply with any of the above, the employee is to be regarded as unfairly dismissed.

Schedule 8 makes other amendments to unfair dismissal law including:

(a) removal of the upper age limit on bringing unfair dismissal claims;

(b) removing the tapering of the basic award for unfair dismissal after age 64 .

\section{REDUNDANCY PAYMENTS}

The law relating to redundancy payments has also been amended, but not as radically as was originally thought. The upper age limit for receipt of a redundancy payment is removed (s 156 ERA 1996 repealed), as are the provisions for tapering the payment after the employee's 64th birthday. The lower age limit in relation to the computing of a period of continuous employment for a redundancy payment is repealed (s 211(2) ERA 1996), but the expected harmonisation of the multiplier for different age bands in respect of the basic award for unfair dismissal and redundancy payments has not materialised. This age differential will remain in place.

There are provisions which deal with occupational pensions, exempting them in a number of important respects from the operation of the Regulations.

Employment tribunals are given jurisdiction in relation to claims brought under the Regulations, with the exception of those against institutions of further and higher education or qualifications bodies (reg 36). The remedies for age discrimination reflect those for other strands of discrimination. (c)

\section{John Sprack}

Barrister, Part-Time Chairman of Employment Tribunals; author of Tottel's Guide to the Age Discrimination Regulations 2006

- This article is based on a lecture given by John Sprack to the Society for Advanced Legal Studies on June 8,2006

\section{EXTRACTS FROM THE EMPLOYMENT EQUALITY (AGE) REGULATIONS 2006}

Regulations 3 and 7, and paragraphs 1 and 2 of regulation 32 of the Employment Equality (Age) Regulations 2006 are reproduced below.

\section{Discrimination on grounds of age}

3-(1) For the purposes of these Regulations, a person ("A") discriminates against another person ("B") if-

(a) on grounds of B's age, A treats B less favourably than he treats or would treat other persons, or (b) A applies to B a provision, criterion or practice which he applies or would apply equally to persons not of the same age group as B, but-

(i) which puts or would put persons of the same age group as $\mathrm{B}$ at a particular disadvantage when compared with other persons, and

(ii) which puts B at that disadvantage,

and A cannot show the treatment or, as the case may be, provision, criterion or practice to be a proportionate means of achieving a legitimate aim.

(2) A comparison of B's case with that of another person under paragraph (1) must be such that the relevant circumstances in the one case are the same, or not materially different, in the other.

(3) In this regulation-

(a) "age group" means a group of persons defined by reference to age, whether by reference to a particular age or a range of ages; and

(b) the reference in paragraph (1)(a) to B's age includes B's apparent age.

\section{Applicants and employees}

7-(1) It is unlawful for an employer, in relation to employment by him at an establishment in Great Britain, to discriminate against a person-

(a) in the arrangements he makes for the purpose of determining to whom he should offer employment;

(b) in the terms on which he offers that person employment; or

(c) by refusing to offer, or deliberately not offering, him employment.

(2) It is unlawful for an employer, in relation to a person whom he employs at an establishment in Great Britain, to discriminate against that person-

(a) in the terms of employment which he affords him;

(b)in the opportunities which he affords him for promotion, a transfer, training, or receiving any other benefit;

(c) by refusing to afford him, or deliberately not affording him, any such opportunity; or

(d) by dismissing him, or subjecting him to any other detriment.

(3) It is unlawful for an employer, in relation to employment by him at an establishment in Great Britain, to subject to harassment a person whom he employs or who has applied to him for employment. 
(4) Subject to paragraph (5), paragraph (1)(a) and (c) does not apply in relation to a person-

(a) whose age is greater than the employer's normal retirement age or, if the employer does not have a normal retirement age, the age of 65 ; or

(b) who would, within a period of six months from the date of his application to the employer, reach the employer's normal retirement age or, if the employer does not have a normal retirement age, the age of 65 .

(5) Paragraph (4) only applies to a person to whom, if he was recruited by the employer, regulation 30 (exception for retirement) could apply.

(6) Paragraph (2) does not apply to benefits of any description if the employer is concerned with the provision (for payment or not) of benefits of that description to the public, or to a section of the public which includes the employee in question, unless-

(a) that provision differs in a material respect from the provision of the benefits by the employer to his employees; or

(b) the provision of the benefits to the employee in question is regulated by his contract of employment; or

(c) the benefits relate to training.

(7) In paragraph (2)(d) reference to the dismissal of a person from employment includes reference- (a) to the termination of that person's employment by the expiration of any period (including a period expiring by reference to an event or circumstance), not being a termination immediately after which the employment is renewed on the same terms; and

(b) to the termination of that person's employment by any act of his (including the giving of notice) in circumstances such that he is entitled to terminate it without notice by reason of the conduct of the employer.

(8) In paragraph (4) "normal retirement age" is an age of 65 or more which meets the requirements of section $98 \mathrm{ZH}$ of the 1996 Act.

\section{Exception for provision of certain benefits based on length of service}

32-(1) Subject to paragraph (2), nothing in Part 2 or 3 shall render it unlawful for a person ("A"), in relation to the award of any benefit by him, to put a worker ("B") at a disadvantage when compared with another worker (“C”), if and to the extent that the disadvantage suffered by B is because B's length of service is less than that of $\mathrm{C}$.

(2) Where B's length of service exceeds 5 years, it must reasonably appear to A that the way in which he uses the criterion of length of service, in relation to the award in respect of which B is put at a disadvantage, fulfils a business need of his undertaking (for example, by encouraging the loyalty or motivation, or rewarding the experience, of some or all of his workers). 